\title{
Kreativitas Guru Dalam Mengajarkan Kecakapan Hidup Pada Anak Usia Dini Di Masa Pandemi COVID-19
}

\author{
Musyafa Ali \\ UIN Sunan Kalijaga, Yogyakarta, Indonesia \\ musyafaali176@gmail.com

\section{Erni Munastiwi} \\ UIN Sunan Kalijaga, Yogyakarta, Indonesia \\ erni.munastiwi@uin-suka.ac.id
}

Abstract: Life skills as a basic in life should be taught to children starting as early as possible, so that one day the child can grow up independent and have a career. However, since the emergence of COVID-19 in early 2020 to date has changed the life order including the scope of education. This requires teachers to make changes in the learning process, including learning life skills in early childhood. The purpose of this research is to reveal how the creativity of PAUD teacher Wadas Kelir in teaching life skills in early childhood during the COVID-19 pandemic. This research is field research. The data in this study was obtained through non-pasrtisipan observations, semi-structured interviews, and documentation for later data processed with inductive techniques. Based on the results of research conducted by researchers can be known that the creativity of teachers in teaching life skills in early childhood in the pandemic becomes one of the keys to the success of teaching life skills, because creativity is one of the keys to success in learning. Creativity by teachers in teaching life skills can be done with a variety of activities and media that are fun, interesting, challenging and new for children.

Keywords: Creativity, life skills, early childhood, COVID-19 pandemic

Abstrak: Kecakapan hidup sebagai dasar dalam kehidupan hendaklah di ajarkan pada anak mulai 
sedini mungkin, agar kelak anak dapat tumbuh mandiri dan berdikari. Namun semenjak kemunculan COVID-19 di awal tahun 2020 hingga saat ini telah merubah tatanan kehidupan termasuk lingkup pendidikan. Hal ini menuntut guru untuk melakukan perubahan dalam proses pembelajaran, termasuk pembelajaran kecakapan hidup pada anak usia dini. Tujuan dari penelitian ini adalah untuk mengungkapkan bagaimana kreativitas guru PAUD Wadas Kelir dalam mengajarkan kecakapan hidup pada anak usia dini di masa pandemi COVID-19. Jenis penelitian yang digunakan oleh peneliti yakni penelitian lapangan dengan menggunakan pendekatan kualitatif. Data dalam penelitian ini diperoleh melalui observasi, wawancara, dan dokumentasi. Dalam menganalisis data peneliti menggunakan tiga tahap, yakni reduksi, penyajian data, dan penarikan kesimpulan. Berdasarkan hasil penelitian yang dilakukan oleh peneliti dapat diketahui bahwa kreativitas guru dalam mengajarkan kecakapan hidup pada anak usia dini di masa pandemi menjadi salah satu kunci keberhasilan pengajaran kecakapan hidup, pasalnya kreativitas adalah salah satu kunci sukses dalam melakukan pembelajaran. Kreativitas yang dilakukan guru dalam mengajarkan kecakapan hidup dapat dilakukan dengan berbagai kegiatan dan media yang menyenagkan, menarik, menantang dan baru bagi anak.

Kata kunci: Kreativitas, kecakapan hidup, anak usa dini, pandemi COVID-19

\section{A. Pendahuluan}

Seiring perkembangan zaman persoalan hidup pun semakin beraneka ragam dan kompleks, hal ini membuat individu harus siap berhadapan dan menghadapi persoalan tersebut. setiap individu dituntut untuk dapat bertahan dengan perbagai persoalan tersebut dengan berbagai bekal. Salah satu bekal yang harus dipersiapkan oleh setiap individu salah satu nya adalah kecakapan hidup. Kecakapan hidup merupakan salah satu bekal penting untuk menghadapi berbagai permasalahan yang semakin berkembang. Hal inilah yang membuat keckapan hidup 
ini menjadi penting diperkenalkan dan diajarkan kepada setiap individu sejak dini.

Pengenalan dan pembelajaran kecakapan hidup merupakan salah satu fondasi terpenting bagi anak. Kecakapan hidup yang diajarkan pada anak akan sangat berpengaruh bagi kehidupan anak dimasa sekarang hingga masa depan (Muhaimin, 2003). Life skill atau kecakapan hidup yang diajarkan pada anak merupakan kegiatan pembelajaran yang memeberikan bekal berupa kecakapan personal, sosial, intelektual dan vokasional sebagai bekal agar anak dapat hidu secara mandiri. Ke empat komponen kecakapan itu sangat penting untuk diterapkan sejak dini (Anwar, 2015). Dengan memiliki kemampuan menguasai kecakapan hidup diharapkan anak dapat bertahan hidup dan bertanggung jawab terhadap dirinya sendiri (Mustofa, 2019).

Dengan dikenalkan dan diajarkannya kecakapan hidup pada anak, diharapkan anak mampu mengurus diri sendiri (self help), membangun citra diri (self image), menambah pengetahuan diri (self knowledge) dan akhirnya mampu menolong orang lain (social skill)(Arifin, 2011). Kecakapan hidup yang diajarkan pada anak usia dini lebih menekankan pada keterampilan teknikal dan keterampilan vokasional, yang tentunya berbeda dengan pendidikan kecakapan hidup di jenjang sekolah menengah. Kecakapan hidup yang diajarkan pada anak usia dini lebih bertujuan untuk mengembangkan dan mengoptimalkan segenap tumbuh kembang anak sekaligus melatih kebiasaan sehari-hari seperti toilet training, belajar menumbuhkan kepercayaan diri dan tidak cengeng, membereskan mainan setelah digunakan dan lain sebagainya (Nurmaliyah, 2010).

Kecakapan hidup (life skill) dapat diajarkan melalui pembiasaan, hal ini dapat dijadikan untuk menumbuhkan sikap mandiri, mampu berinteraksi dengan lingkungan dan mengasah (basic skill) yang berguna untuk kehidupan anak selanjutnya (Sudjana, 2007). Tujuan Pendidikan kecakapan hidup (life skill) adalah mempersiapkan anak dengan berbagai kecakapan dan mengoptimalkan segenap perkembangannyya (Muhdi, Senowarsito, 2012). Dengan kata lain kecakapan hidup dapat membentuk kepribadian anak menjadi pribadi yang tidak mudah berputus asa dan pantang menyerah serta bertanggung jawab (Shaumi, 2015). Untuk itu selayaknya Pendidikan 
kecakapan hidup menjadi point penting dan fokus utama dalam Pendidikan anak usia dini (Widayati, 2013).

Ciri utama yang menandakan dari keberhasilan kegiatan belajar adalah perubahan perilaku peserta didik menuju arah yang lebih baik. PAUD sebagai lembaga pertama bagi anak usia dini adalah dituntut untuk dapat memberikan bekal bagi anak degan berbagai kecakapan. Pendidikan kecakapan hidup pada anak bertujuan memberikan bekal keterampilah hidup seharihari pada anak, sehinga kelak anak dapat hidup mandiri(Prihatiningsih, 2013). Sebab Pendidikan yang terencana dan terstruktur pada anak merupakan investasi jangka panjang yang diharapkan dapat mendatangkan benefit pada setiap fase kehidupannya. Terlebih lagi investasi yang dilakukan tepat berada pada masa emas (golden age) perkembangan anak yang akan memberikan benefit yang berlipat ganda karena diberikan pada masa peka dan masa kritis perkembangannya. Artinya masa dimana anak memiliki kesiapan dalam menerima berbagai stimulus Pendidikan yang diberikan baik dari dalam maupun luar lingkungannya (Muhibah, 2011).

Namun setelah World Health Organization (WHO) menetapkan Corona Virus Disease sebagai pandemi pada Maret lalu (Zhang, Y., Jiang, B., Yuan, J., \& Tao, 2020). Kini sistem pendidikan harus berubah secara drastis. Seiring dengan kepanikan yang melanda akhirnya pemerintahan melalui Kementerian Pendidikan dan Kebudayaan pun menetapkan kebijakan baru yakni study from home atau lebih dikenal dengan belajar dari rumah (Ardiyanti \& Munastiwi, 2020). Dengan terbitnya kebijakan ini guru dituntut untuk berkreasi dan menginovasi segala kegiatan yang sebelumnya telah disusun untuk menciptakan sistem pemebelajaran baru bagi anak selama anak belajar di rumah. Kebijakan ini berlaku untuk seluruh jenjang pendidikan, mulai dari pendidikan anak usia dini hingga perguruan tinggi (Pramana 2020).

Kebijakan ini menimbulkan permasalahan baru, hal ini dikarenakan pembelajaran harus dilaksanakan secara daring. Sedangkan seperti yang kita ketahui bahwa pembelajaran anak usia dini adalah pembelajaran berbasis bermain dan belajar dengan melakukan atau learning by doing, begitu pula dalam proses pembelajaran kecakapan hidup. Ketika pembelajaran harus dilakukan secara daring, namun anak juga harus belajar 
dengan melakukannya maka dari sinilah muncul sebuah pertanyaan. Bagaimana seorang guru harus melakukan dan mengkombinasika ketiga permasalhan tersebut. Seperti yang kita ketahui pembelajaran kecakapan hidup pada anak usa dini adalah embelajaran berbasis keterampilah yang harus dilakukan oleh anak. Sehingga saat anak belajar tentang kecakapan hidup maka anak tidak bisa hanya dengan endengar atau melihat melainkan annak harus terlibat atau melakukannya secara langsung, agar anak dapat merasakan dan mempraktikannya.

Sebagai contoh sederhana kegiatan menyiram tanaman, mungkin dengan melihat gambar saja anak tahu, kalau itu adalah kegiatan menyiram tanaman, akan tetapi anak tidak bisa merasakan, ataubahkan anak tidak bisa mempraktikannya. Mulai dari bagaimana memegang penyiran, mengisi air, menyiramkan ke bunga dan sebagainya. oleh karena itu pembelajaran kecakapan hidup harus dilakukan secara langsung, hal ini sesuai dengan karakteristik belajar anak yakni belajaar sambil melaakukan. Maka disini guru dituntut untuk dapat menciptakan kegiatan belajar yang sesuai dengan kebutuhan dan karakteristik anak, khususnyaa dimasa pandemi ini.

Adapun penelitian sebelumnya dilakukan oleh Shofiyurrohman Kusuma, adapun judul penelitian yang dilakukan yakni berkaitan dengan pembentukan kecakapan hidup (life skill) melalui program literasi pada pembelajaran alQur'an. Hasil dari penelitian tersebut yakni kecakapn hidup yang dibentuk berupa kecakapan berpikir, kecakapan sosial, kecakapan bekerja sama, kecakapan kejujuran dan kecakapan berpikir ilmiah. Bentuk kreativitas pengembangann kecakapan hidup dilakukan dengan cara pembelajaran al-quran (Rukmana, 2019).

Kemudian ada juga penelitian dari Dwi Nur Hayati dkk, dengan judul Mengajarkan Daily Life Skill Pada Anak Usia 6 Tahun Yang Menderita Retardasi Mental Dengan Pendekatan Montessori. Dimana hasil dari penelitian tersebut menunjukan bahwasanya pembelajaran kecakapan hidup ditujukan agar anak memiliki kemandirian dan keterampilan dasar dalam hidup seperti memakai baaju, menagncing baju dan lain sebaginya. Bentuk kreativitas yang dilakukan yakni guru mengadopsi teknik Montessori yakni dengan menggunakan alat 
peraga asli atau menggunakan alat peraga yang menyerupai benda asli sebagai media belajar anak (Dwi Nurhayati Adhani, Dewi Mayangsari, 2017).

Selanjutnya penelitian tentang kecakapan hidup juga dilakukan oleh Ayu Nur Shaumi dengan judul Pendidikan Kecakapan Hidup (Life Skill) Dalam Pembelajaran Sains Di SD/MI. Hasil dari penelitian ini menunjukan bahwasanya pembelajaran kecakapan hidup diintegrasikan kedalam mata pelajaran IPA, dengan cara memasukan aspek-aspek keterampilan hidup saat melakukan pembelajaran IPA. Dalam penelitian tersebut bentuk kreativitas guru ditunjukan dalam mengajarkan kecakapan hidup pada anak melalui pembelajaran IPA, dimana anak belajar IPA juga belajar kecakapan hidup (Shaumi, 2015).

Berangkat dari permasalahan yang telah dipaparkan di atas dan hasil penelitian sebelumnya, peneliti tertarik untuk meneliti bagaimanakah guru PAUD Wadas Kelir Purwokerto dalam mengajarkan kecakapa hidup pada anak usia dini di masa pandemi COVID-19?. Berdasarkan perumusan masalah tersebut maka tujuan dari penelitian ini adalah untuk mendeskripsikan kreativitas guru PAUD Wadas Kelir dalam mengajarkan kecakapan hidup pada anak usia dini di masa pandemi COVID19. Hasil penelitian ini akan memberikan pembaharuan bagi pendidik ataupun orang tua dalam melaksanakan kegiatan pembelajaran kecakapan hidup pada anak, khususnya di masa pandemi COVID-19.

\section{B. Pembahasan}

\section{Kajian Teori}

\section{a. Kreativitas}

Menurut Rodhes kreativitas dirumuskan dalam istilah 4P: Person, Process, Press, Product. Person diartikan sebagai pribadi atau individu. Process dimaknai sebagai suatu usaha berpikir untuk menemukan gagasan-gagasan baru. Press diartikan sebuah keinginan atau dorongan untuk mencipta atau menemukan hal-hal kreatif. Product diartikan sebagai hasil atau sesutu yang dibuat yang sebelumnya pernah ada. Pribadi yang kreatif merupakan pribadi yang dapat mengkombinasikan 4P. (Munandar, 1999). Kreativitas guru menjadi sangat penting dalam proses pembelajaran, hal ini karena dengan kreativitas 
guru dapat meningkatkan kualitas dari pembelajaran itu sendiri (Taher, 2019) . Saat dikaitkan dengan kondisi saat ini, dimana sedang dalam kondisi pandemi maka kreativitas guru dalam pembelajaran menjadi sangat penting agar pembelajaran dapat berjalan secara efektif dan menyenangkan.

\section{b. Kecakapan Hidup}

Beberapa ahli berpendapat bahwasanya kecakapan hidup adalah keterampilan individu dalam memecahkan problematika hidup yang dihadapi, selain itu keterampilan hidup juga mengajarkan seseorang untuk bersikap kreatif dalam memecahkan persoalan (Muhaimin, 2003). Life Skill menurut Anwar yakni ketahanan individu dalam berinteraksi dan beradaptasi dengan lingkungan di sekitarnya, keterampilan ini diantaranya yakni keterampilan untuk mengambil keputusan, adaptasi, komunikasi dan interaksi, dan berpikir dan bertindak kreatif dalam memecahkan masalah. (Anwar, 2015). World Health Organization (WHO) dalam Life Skills Education in Schools, Life Skills adalah berbagai keterampilan atau kemampuan untuk dapat beradaptasi dan berperilaku positif dalam kehidupan sehari-hari (WHO Programme on Mental Health, 1997). Tim Broad-Based Education memaknai Life Skill sebagai keterampilan individu untuk mencari solusi atas sebuah problem, kemudian mampu melakukan pemecahan masalah dengan kreatif (Depdiknas, 2002).

Ruang lingkup kecakapan hidup meliputi aspek-aspek: kemampuan, kesanggupan dan keterampilan. Aspek kemampuan dan kesanggupan tercakup dalam kecakapan berpikir, sedangkan aspek keterampilan tercakup dalam kecakapan bertindak. Kecakapan berpikir pada dasarnya merupakan kecakapan menggunakan pikiran/rasio secara optimal. Kecakapan berpikir mencakup antara lain kecakapan menggali dan menemukan informasi (information searching), kecakapan mengolah informasi dan mengambil keputusan secara cerdas (information processing and decision making skills) serta kecakapan memecahkan masalah secara arif (Arifin, 2011).

\section{c. Anak Usia Dini}

Anak usia dini di Indonesia sendiri diartikan sebagai anak yang berada dalam rentang usia 0-6 tahun. Bredekamp membagi anak usia dini menjadi tiga kelompok, yakni (1) 
kelompok bayi hingga dua tahun, (2) kelompok 3 hingga 5 tahun, dan (3) kelompok 6 hingga 8 tahun. (Fadillah, 2012). Hasan Alwi dkk, dalam Kamus Besar Bahasa Indonesia mengungkapkan bahwa anak adalah manusia yang masih kecil, yaitu yang baru berumur enam tahun. Jadi jika diartikan secara bahasa anak usia dini adalah sebutan bagi anak yang berusia antar 0-6 tahun. (Wiyani, 2015).

\section{Metode}

Jenis penelitian ini yakni penelitian lapangan dengan menggunakan pendekatan kualitatif. Peneliti melaksanakan proses penelitan secara mendalam melalui penelitian deskriptif kualitatif dengan jenis studi lapangan melalui kegiatan analisis proses Kreativitas Guru Dalam Mengajarkan Kecakapan Hidup Pada Anak Usia Dini Di PAUD Wadas Kelir (Moleong, 2016).

Pengumpulan informasi yang dilakukan oleh peneliti melalui wawancara dan mengamati kegiatan-PAUD Wadas Kelir observasi dan dokumentasi, dokumen yang dikumpulkan oleh peneliti berupa dokumen yang berkaitan dengan kegiatan kecakapan hidup yang diajarkan, baik dari sekolah ataupun media sosial PAUD Wadas Kelir. Dalam menganalisis data peneliti menggunakan tiga tahap yakni reduksi data, penyajian data, dan penarikan serta pengujian kesimpulan (drawing and verifying conclusion) (Ibrahim, 2015).

\section{Jenis Kecakapan Hidup yang Dikembangkan di PAUD Wadas Kelir}

\section{a. Kecakapan Personal}

Kecakapan personal yang diajarkan di PAUD Wadas Kelir yakni kecakapan yang berupa kemampuan mengenal kemampuan diri, berpikir rasional, dan penghayatan diri sebgai mahluk Tuhan yang Maha Esa, anggota masyarakat, dan warga negara, serta menyadari dan mensyukuri kelebihan dan kekurangan yang dimiliki, sekaligus menjadikannya sebagai modal dalam meningkatkan dirinya sebagai individu yang bermanfaat bagi diri sendiri dan lingkungan.

b. Kedua kecakapan sosial atau kecakapan antar personal

(interpersonal skills)

Kecakapan Sosial yang diajarkan di PAUD Wadas Kelir merupakan kecakapan yang mengajarkan anak untuk memilki kemampuan berkomunikasi dengan empati, dan bekerjasama. 
c. Ketiga kecakapan akademik

Kecakapan akademik yang diajarkan di PAUD Wadas Kelir merupakan kecakapan yang mengajarkananak untuk mampu berpikir secara kreatif, mandiri dan mampu melakukan problem solving.

d. Kecakapan Vokasional (Vocational Skill)

Kecakapan vokasional yang diajarkan di PAUD Wadas Kelir merupakan kecakapan yang mengajarkan anak untuk mampu bekerjasama dan melakukan aktivitas sosial dalam masyarakat (Arifin, 2011).

Jenis-jenis kecakapan hidup yang diajarkan oleh guru pada anak di masa pandemi di PAUD Wadas Kelir meliputi empat jenis kecakapan hidup tersebut. Dimana kecakapan hidup tersebut diajarkan pada anak melalui berbagai kegiatan dan media yang menyenangkan. Pembelajaran kecakapan hidup tersebut dilakukan secara daring dengan cara guru membuat konten menarik terkait pembelajaran tersebut untuk kemudian diajarkan pada anak. konten-konten tersebut berupa gambar, video ataupun rekaman suara.

Kreativitas guru dalam megajarkan kecakapan hidup tersebut yakni dengan menggunakan media elektronik yakni gadget yang kemudian diperinci lagi menggunakan sosial media yang ada, seperti youtube, instagram, whatsapp, video, dan rekaman suara. Selain menggunakan media elektronik guru juga memberikan tugas langsung atau praktik pada anak. Kemudian yang terakhir yakni teknik kombinasi dimana guru menggunakan media elektronik guru juga memberikan tugas yang harus dipraktikan pada anak, sehingga setelah anak belajar dengan melihat dan mendengar kemudian anak mempraktikannya secara langsung.

Setelah melakukan pembelajaran kecakapan hidup, guru juga melakukan evaluasi, baik evaluasi guru yang berkaitan dengan proses pembelajaran ataupun evaluasi pada peserta didik. Evaluasi guru biasanya dilakukan setelah guru melakukan pembelajaran dengan memberikan laporan terkait media ataupun pelaksanaan pembelajaran. Hal ini dilakukan agar apabila terjadi kesalahan atau ketidaksesuaian guru dapat memperbaikinya.

Untuk evaluasi pada pembelajaran anak biasanya guru mengevaluasi secara langsung saat pembeajaran menggunakan video call, namun saat tugas berupa proyek atau pekerjaan 
maka guru akan mengevaluasi anak dengan cara menanyakan pekerjaan anak pada orang tua, selain itu guru juga dapat mengevaluasi anak dengan hasil pekerjaan yang berupa foto atau video yang dikirim oleh orang tua sebagai bukti anak telah melakukan pekerjaannya. Dokumentasi ini kemudian juga dijadikan sebuah dokumen elektronik dengan cara guru mengarsipkan baik di komputer ataupun di instagram.

\section{Kreativitas guru dalam mengajarkan kecakapan hidup pada anak usia dini di masa pandemi COVID-19 di PAUD Wadas Kelir}

Dalam mengajarkan kecakapan hidup guru-guru di PAUD Wadas kelir menggunakan metode proyek, dimana guru memberikan proyek atau tugas tugas pada melalui orang tua kemudian anak-anak yang melaksanakan langsung tugas tersebut atau anak-anak terlibat langsung dalam kegiatan sehari-hari yang dilakukan oleh orang tua sebagai tugas dari guru. Adapun proyek yang diberikan oleh guru untuk anak-anak yakni diantaranya cooking day, aku pahlawan Ibuku, cinta lingkungan dan juga bercocok tanam, aku anak pintar dan mandiri, senangnya berbagi, permainan kreatif, aku anak sholeh.

\section{a. Cooking day}

Cooking day yaitu kegiatan dimana anak melakukan kegiatan masak atau menyediakan makanan. Pelaksanaan kegiatan Cooking Day yakni dengan cara guru memberikan proyek kepada orang tua untuk kemudian orang tua menyampaikan kepada anak. cooking day yang dilakukan dapat dilakukan oleh anak secara mandiri ataupun dilakukan oleh orang tua bersama anak. Adapun jenis cooking day yang telah dilaksanakan selama pandemi yakni, anak membuat dan menyajikan teh untuk orang tuanya, anak membuat makanan khas banyumas yakni mendoan, dan memasak bebas bersama orang tua. Dalam pelaksanaanya anak melakukan atau memasak atau melakukan pekerjaan secara mandiri namun tetap dalam pengawasan dan pendampingan orang tua Cooking Day merupakan salah satu kegiatan kecakapan personal, dimana cooking day mengajarkan anak untuk mampu mengurus dirinya sendiri sekaligus bentuk pengekspresian atas kemampuan dan kemampuan yang dimiliki, selain itu dengan kegiatan ini anak juga diajarkan kecakapan sosial dimana, hal ini dikarenakan 
dalam kegiatan cooking day yang dilakukan bersama orang tua disitu anak belajar bersosialisasi dengan orang tua sebagai fasilitator dan rekan dalam mengerjakan tugas tersebut. Adapun kegiatan ini bertujuan untuk memberikan pengalaman langsung sebanyak-banyaknya pada anak, menumbuhkan kemandirian anak, melatih emosi dan sosial anak.

\section{b. Aku pahlawan ibuku}

Aku pahlawan ibuku adalah kegiatan dimana pada hari itu anak diajarkan untuk memakai sebuah pakaian superhero dan kemudian anak membantu orang tuanya di hari itu, misal anak memakai pakaian frozen, spiderman atau yang lainnya, kemudian anak membantu orang tua menyapu, mengepel, mencuci piring dan lain sebagainya. Aku pahlawan ibuku adalah salah satu jenis kegiatan kecakapan hidup yang mengembangakan kecakapan personal dan sosial. Kecakapan pesonal pada kegiatan aku pahlawan ibuku mengajarkan anak untuk melatih keterampilan hidup yang berkaitan dengan keterampilan yang dalam melaksanakan kegiatan sehari-hari. Dalam proses pelaksanaannya guru memberikan proyek ini pada orang tua melalui grup WA dan lembar kerja, kemudian orang tua menginstruksikan pada anak untuk melaksanakan tugasnya. Hal ini bertujuan untuk melibatkan anak dalam kegiatan sehari-hari diharapkan nantinya kegiatan ini juga menjadi kebiasaan yang akan diterapkan oleh anak-anak hingga dewasa, sehingga anak dapat tumbuh mandiri.

\section{c. Cinta lingkungan dan bercocok tanam}

Kegiatan cinta lingkungan dan bercocok tanaman yakni kegiatan dimana anak-anak diajarkan untuk menanam sebuah tanaman mulai dari menyiapkan tanah, memindah tanah ke wadah, menanam biji, menyiram dan merawatnya hingga memperhatikan tumbuh dari tumbuhan tersebut. Selain itu kegiatan cinta lingkungan yang diajarkan oleh guru PAUD yakni anak diajarkan untuk menyiram tanaman kemudian membersihkan lingkungan sekitar dengan cara menyapu dan membersihkan sampah-sampah di sekitar rumah. Kecakapan ini masuk dalam jenis kecakapan, personal, dan akademik dan vokasional. Letak dari kecakapan personal yakni anak dapat menunjukan kemandirian dalam proses pelaksanaan penanaman, perawatan dan kegiatan membersihkan lingkungan. Kemudian kecakapan vokasional ditunjukan 
dengan kemampuan anak melakukan cocok tanam, setelah anak melakukan cocok tanam anak akan ditanyai oleh guru terkait dengan proses pelaksanaan, dimana anak akan dilatih untuk berkata jujur dalam proses cocok tanam, biasanya anak akan ditanya oleh guru terkait pelaksanaan cocok tanam dilakukan sendiri atau dibantu oleh orang tua. Kecakapan akademik dalam kecakapan hidup aku cinta lingkungan dan bercocok tanam adalah, anak belajar sains secara langsung tentang bercocok tanam, dan mengamati proses pertumbuhan tanaman yang ditanamnya. Tujuan dari pembelajaran kecakapan hidup ini yakni mengajarkan anak untuk cinta lingkungan, kebersihan dan penghargaan terhadap tanaman atau tumbuhan.

\section{d. Aku anak pintar dan mandiri}

Aku anak pintar dan mandiri adalah kegiatan dimana anak mampu melaksanakan tugas belajar, bermain ataupun proyek lain yang diberikan oleh guru pada anak secara mandiri. Sebagai contoh saat anak mendapatkan tugas mewarnai, kolase, atau tugas lainnya yang beriakitan dengan belajar ataupun bermain maka anak harus mengerjakan tuga tersebut secara mandiri. Kegiatan aku anak pintar dan mandiri merupakan salah satu jenis kecakapan vokasional dan juga personal. Kecakapan personal yang ditunjukan oleh anak dalam kegiatan aku anak pintar dan mandiri yakni anak mampu menyelesaikan tugastugas ataupun permasalahan yang diberikan oleh guru, selain itu anak juga diajarkan untuk belajar tentang problem solving atau pemecahan masalah secara mandiri. Kecakapan vokasional ditunjukkan oleh anak dengan cara anak mengerjakan tugas secara pribadi dan jujur. Untuk tugas anak akan dikirimkan oleh orang tua dengan cara memfoto anak dengan tugasnya ataupun orang tua memvideo anak saat anak sedang mengerjakan tugas. Tujuan dari kegiatan Aku anak pintar dan mandiri yakni selain menjadikan anak mandiri dalam belajar dan tidak selalu tergantung pada orang tua, selain itu anak juga menjadi lebih kreatif dalam memecahkan setiap permasalahan yang dihadapinya. Selain itu kegiatan aku anak mandiri juga diajarkan bukan hanya dalam kegiatan belajar, akan tetapi hal yang lebih sederhana juga diajarkan seperti, memkai baju, mengancing baju, memakai celana, dan toilet training. 


\section{e. Senangnya berbagi}

Senangnya berbagi merupakan salah satu kegiatan yang dilaksanakan pada tanggal 1 bulan Muharram dalam rangka memperingati hari kelahiran nabi. Pada hari itu anak-anak disuruh oleh guru untuk membuat makanan dan kemudian makanan itu dibagikan kepada tetangga yang ada di sebelah rumahnya. Kegiatan ini bertujuan untuk mengembangkan ke perkembangan sosial anak agar anak mampu bersosialisasi dengan orang lain. Selain itu dengan kegiatan ini juga menanamkan pada diri anak untuk mau dan suka berbagi dengan orang lain yang ada disekelilingnya. Kegiatan senangnya berbagi merupakan kegiatan yang dilakukan dalam rangka mengembangkan kecakapan sosial dan vokasional. Kecakapan sosial dan vokasional merupakan kecakapan hidup dimana anak-anak diajarkan untuk dapat bersosialisasi dengan lingkungan disekitar anak. dalam kegiatan ini anak diajarkan untuk bersosialisasi dan bersentuhan langsung dengan cara memberikan makanan kepada tetangganya. Dengan kegiatan ini diharapkan kepekaan sosial anak dapat berkembang dengan baik.

\section{f. Games kreatif}

Anak-anak selalu identik dengan kegiatan belajar denagn bermain ataupun sebaliknya, yakni bermain sambil belajar. salah satu kegiatan belajar dan bermian anak yang dilakukan di PAUD Wadas Kelir selama pandemi yakni dengan membuat games-games kreatif bagi anak, kegiatan ini bertujuan mengembangkan segenap kemampuan anak. Games kreatif merupakan kegiatan games yang dibuat oleh guru guna pembelajaran anak, adapun games-games yang dilakukan oleh anak selama pandemi diantaranya, lose part, games konsentrasi, games pola sandal, seluncur koin, play dough, dan lain sebagainya. Selain fisik motorik, perkembangan kognitif dan lainnya pun turut dikembangkan melalui games ini. Kegiatan games kreatif merupakan salah satu kegiatan yang bertujuan untuk mengembangkan kecakapan hidup personal dan akademik. Dalam proses pelaksanaannya anak akan melihat video sebagai instruksi dari guru, kemudian anak meniru, dan hasilnya berupa foto dan video anak yang melakukan games tersebut. Kecakapan personal yang ditunjukan dalam games kreatif ini yakni anak melakukan permainan secara mandiri, dan 
dalam pelaksanaannya anak diajarkan konsep problem solving. Kecakapan akademik dalam kegiatan games kreatif tercover dalam permainan anak. Tujuan utama dari games kreatif adalah untuk mengoptimalkan segenap perkembangan anak, mulai dari fisik motorik, sosial emosional, kognitif dan lain sebagainya. Selain itu melalui permainan ini anak juga belajar pemecahan masalah.

\section{g. Aku anak sholeh}

Aku Anak Sholeh merupakan kegiatan yang diajarkan oleh guru-guru pada anak berupa menghafalkan doa harian, asmaul husna, pengenalan sholat wajib dan lain sebagainya. Pembelajaran dilakukan melalui video yang dibuat oleh guru, ataupu melalui pembelajaran dengan cara video call antara guru dengan anak. Tujuan dari pembelajaran ini yakni sebagai pengenalan Tuhan kepada anak dan juga menanamkan keimanan, akhlak sekaligus pembentukan karakter religius anak. kegiatan aku anak sholeh merupakan salah satu kegiatan yang dilakukan dalam rangka mengembangkan kecakapan personal, dimana anak diajarkan untuk beribadah dan mengimani Allah. Selain itu kegiatan ini diharapkan dapat menjadi karakter yang tertanam pada dir anak. kegiataan ini juga berguna untuk mengembangkan agama dan moral anak. Dalam proses pelaksanaannya kegiatan pembelajaran agama dilakukan secara bertahap dan berulang-ulang. Pembelajaran ini juga dilakukan dengan gerakan-gerakan dan lagu, dengan harapan agar anak lebih mudah dalam menghafal dan memahaminya.

\section{Implikasi pembelajaran kecakapan hidup (life skill) di PAUD Wadas Kelir}

Implikasi dari pembelajaran kecakapan hidup yang diajarkan oleh guru PAUD Wadas Kelir pada peserta didiknya dapat ditinjau dari beberapa aspek diantaranya yakni, anak menjadi lebih mandiri, dari hasil wawancara dengan Bunda PAUD Wadas Kelir menyatakan bahwasanya setelah belajar kecakaapaan hidup anak menjadi leih mandiri, sebagai contoh anak mau memakai celana sendiri, mengancing baju sendiri, makan sendiri, belajar mandiri dan lain sebagainya. Anak menjadi lebih kreatif, hal ini dibuktikan dengan bentuk-bentuk laporan tugas anak yang diterima oleh guru. Kreatif anak di 
bentuk melalui kegiatan bermain kreatif, tugas-tugas mandiri serta kegiatan eksplorasi. Dari segi kecakapan sosial, anak mau berbagi dengan orang lain. Selain itu anak juga mampu memecahkan permasalahannya sendiri, hal ini dipicu dengan adanya pembelajaran-pembelajaran kreatif yang dilakukan oleh anak. Dalam pembelajaran ini anak dihadapkan dengan permasalahan ringan yang harus diselesaikaan sendiri, baik ketika belajar ataupun bermain. Sebagai contoh anak mampu melakukan tantangan yang diberikan oleh guru.

Selain itu pembelajaran kecakapan hidup ini juga berdampak pada seluruh aspek perkembangan anak, hal ini dapat dilihat dari capaian perkembangan belajar anak. Dimana enam aspek perkembangan anak, yakni, kognitif, sosial emosional, fisik motorik, bahasa, seni, dan nilai agama moral anak juga ikut berkembang meskipun pembelajaran dilakukan secara daring.

\section{Simpulan}

Dari hasil penelitian yang dilakukan oleh peneliti di lapangan dapat diambil kesimpulan bahwasanya ada empat kecakapan hidup yang diajarkan oleh guru-guru di PAUD Wadas Kelir. Empat kecakapan tersebut yakni kecakapan personal, sosial, akademik dan vokasional. Kemudian dalam mengajarkan kecakapan hidup pada anak anak usia dini di masa pandemi covid 19, guru menggunakan teknik pemberian proyek pada orang tua, dimana proyek tersebut nantinya dikerjakan oleh anak sendiri ataupun dikerjakan bersama antara anak dan orang tua. Adapun proyek-proyek yang diberikan oleh guru guna mengajarkan kecakan hidup pada anak diantaranya cooking day, aku pahlawan Ibuku, cinta lingkungan dan juga bercocok tanam, aku anak pintar dan mandiri, senangnya berbagi, game kreatif dan aku anak sholeh. Pembelajaran kecakapan hidup yang diajarkan oleh guru PAUD Wadas Kelir berdampak pada sikap kemandirian dan kepedulian anak, hal ini dapat dlihat dari sikap yang di tunjukan anak dalam kehidupan sehari-hari.

Kelebihan dari hasil penelitian ini yakni bentuk-bentuk inovasi dan kreativitas yang dilakukan oleh guru dalam mengajarkan kecakapan hidup pada anak usia dini di masa pandemi COVID-19 dapat menjadi bahan pembaharuan bagi guru dalam mengajarkan kecakapan hidup pada anak usia dini. 
Selain itu meskipun dalam pemberian tugas atau proyek pada anak disampaikan secara on line namun hasil serta dampak dari pembelajaran kecakapan hidup yang diajarkan dapat diterima serta berdamak pada kemandirian serta kepedulian anak. Dalam memberikan instruksi proyekpun guru menjad lebih kreatif, hal ini dikarenakan guru harus berusaha agar apa yang disampaikan atau di instruksikan dapat dipahami dengan mudah oleh anak.

Kekurangan dari penelitian ini adalah, meskipun penelitian ini penelitian lapangan, namun peneliti tidak dapat mengamati kegiatan anak secara langsung, peneliti hanya mendapat informasi dari guru, serta dokumentasi dan publikasi di media sosial PAUD Wadas Kelir. Melalui Instagram peneliti melihat dokumentasi berupa foto dan video kegiatan anak.

\section{Referensi}

Anwar. (2015). Pendidikan Kecakapan Hidup. Alfabeta. Ardiyanti, S., \& Munastiwi, E. (2020). PERAN ORANG TUA DALAM MEMANFAATKAN MEDIA SOSIAL BAGI. 4(2). Arifin, Z. (2011). Konsep dan Model Pengembangan Kurikulum. PT. Remaja Rosdakarya.

Depdiknas. (2002). Pendidikan Berorientasi Kecakapan Hidup (Life Skill) Melalui Pendekatan Broad-Based Education. Departemen Pendidikan Nasional.

Dwi Nurhayati Adhani, Dewi Mayangsari, S. F. F. (2017). MENGAJARKAN DAILY LIFE SKILL PADA ANAK USIA 6 TAHUN YANG MENDERITA RETARDASI MENTAL DENGAN PENDEKATAN MONTESSORI. Pedagogi : Jurnal Anak Usia Dini Dan Pendidikan Anak Usia Dini, 3(3), 52-60. http://103.114.35.30/index.php/Pedagogi/article/view/42 37

Fadillah, M. (2012). Desain Pembelajaran PAUD, Tinjauan Teoritik dan Praktik. Ar-Ruz Media.

Ibrahim. (2015). Metode Penelitian Kualitatif. Alfabeta.

Moleong, L. J. (2016). Metodologi Penelitian Kualitatif. PT Rosdakarya.

Muhaimin. (2003). Arah Baru Pengembangan Pendidikan Islam. Nuansa.

Muhdi, Senowarsito, L. S. (2012). Pendidikan Kecakapan hidup (Life skil) melalui child friendly teaching model sebagai dasarmembnagun karakter siswa. Jurnal UPGRIS. 
Muhibah, B. (2011). Pengembangan Kecakapan Hidup anak usia dini dalam keluarga. Universitas Negeri Semarang.

Munandar, U. (1999). Kreativitas dan Keberbakatan Strategi Mewujudkan Potensi Kreatif. Gramedia.

Mustofa, E. (2019). PENINGKATAN KECAKAPAN HIDUP (LIFE SKILL) MELALUI PEMBIASAAN MENCUCI TANGAN (Penelitian Tindakan Pada Anak Kelompok A TK Al- Fidaa Kec. Tambun Selatan Kab. Bekasi, Tahun Ajaran 2015). Almarhalah / Jurnal Pendidikan Islam, 1, 25-32.

Nurmaliyah, S. L. P. dan F. (2010). Perencanaan Pembelajaran pada Bidang Studi Tematik, Muatan Lokal, Kecakapan Hidup, Bimbingan dan Konseling. UIN-Maliki Press.

Pramana, C., \& Semarang, U. N. (2020). Pembelajaran Pendidikan Anak Usia Dini ( PAUD) Dimasa Pandemi Covid19 Riwayat Artikel : Address : Pasca Sarjana Universitas Negeri Semarang. August. https://doi.org/10.35473/ijec.v2i2.557

Prihatiningsih, W. (2013). Upaya Peningkatan Kecakapan Hidup Melalui Metode Bermain Peran Pada Anak Usia 4-5 Tahun Di Tkit Taruna Teladan Delanggu Tahun Ajaran 2012/2013. Universitas Muhamadiyah Surakarta.

Rukmana, S. K. (2019). PEMBENTUKAN KECAKAPAN HIDUP ( LIFE SKILL ) MELALUI PROGRAM LITERASI PADA PEMBELAJARAN AL- QUR 'AN DI MTS DARUL HIKMAH PRASUNG BUDURAN. UNIVERSITAS ISLAM NEGERI SUNAN AMPEL.

Shaumi, A. N. (2015). Pendidikan Kecakapan Hidup (Life Skill) dalam Pembelajaran Sains di SD/MI. Pendidikan Dan Pembelajaran Dasar, 2(2), 246.

Sudjana, D. (2007). Pendidikan Nonformal, Jurnal dalam Ilmu dan Aplikasi Pendidikan Bagian 2 Ilmu Pendidikan Praktis. Imperial Bhakti Utama.

Taher, S. M. (2019). Peran Guru Dalam Mengembangkan Kreativitas Anak Usia Dini Di TK Islam Terpadu Salsabila AlMuthi'in Yogyakarta. 2, 35-50.

WHO Programme on Mental Health. (1997). Life Skills Education in Schools, WHO, Division of Mental Health and Prevention of Substance Abuse. Geneva.

Widayati, T. (2013). Pengembangan Karakter Anak Usia Dini Character Development of the Early Aged Children. Jurnal Ilmiah VISI P2TK PAUDN, 8(2), 85-93. 
52 | Musyafa Ali \& Erni Munastiwi

Wiyani, N. A. (2015). Manajemen PAUD Bermutu, Konsep dan Praktik MMT di KB, TK/RA. Gava Media.

Zhang, Y., Jiang, B., Yuan, J., \& Tao, Y. (2020). The impact of social distancing and epicenter lockdown on the COVID-19 epidemic in mainland China: A data-driven SEIQR model study. MedRxiv, 2019(December 2019), 2020.03.04.20031187. https://doi.org/10.1101/2020.03.04.20031187 